\title{
Selected Bibliography
}

Ackerknecht, E. H., Medicine at the Paris hospital 1794-1848, Baltimore, John Hopkins Press, 1967.

Berry, D. and Mackenzie, C., Richard Bright, 1789-1858: physician in an age of revolution and reform, London, Royal Society of Medicine Services, 1992.

Brock, W. H., 'The life and work of William Prout', Medical History, 1965, 9: 101-26.

Bynum, W. F. and Porter, R. (eds), Companion encyclopedia of the history of medicine, 2 vols, London and New York, Routledge, 1993.

Cameron, J. S., 'A historical review', in Cameron, J. Stewart and Glassock, Richard J. (eds), The nephrotic syndrome, New York, Marcel Dekker, 1988.

'John Bostock MD, FRS (1773-1846): physician and chemist in the shadow of a genius', Am. J. Nephrol., 1994, 14: 365-70.

— and Hicks J., 'Frederick Akbar Mahomed and his role in the description of hypertension at Guy's Hospital', Kidney International, 1996, 49: 1488-506.

Chasis, H. and Goldring, W. (eds), Homer William Smith Sc.D.: his scientific and literary achievements, New York, New York University Press, 1965.

Coley, Noel G., 'George Owen Rees MD, FRS (1813-89): pioneer of medical chemistry', Medical History, 1986, 30: 173-90.

Dezeimeris, J. E., Ollivier, C. P., Raige-Delorme, J., Dictionnaire historique de la médecine, ancienne et moderne, 4 vols, Paris, Béchet jeune, 1828-39.

Fogazzi, G. B., Cameron J. S., Ritz, E. and Ponticelli, C., 'The history of urinary microscopy to the end of the nineteenth century', Am. J. Nephrol., 1994, 14: 452-7.

Garrison, F. H., An introduction to the history of medicine, 4th ed., Philadelphia and London, W.B. Saunders, 1929.

Jacyna, S., 'John Hughes Bennett and the origins of medical microscopy in Edinburgh: Lilliputian wonders', Proc. R. Coll. Physicians (Edin.), 1997, 27 (Supp. 3): 12-21.

Major, Ralph H., Classic descriptions of disease, 3rd. ed., Springfield, ILL, Charles C. Thomas, 1959.

Richet, Gabriel, 'From Bright's disease to modern nephrology: Pierre Rayer's innovative method of clinical investigation', Kidney International, 1991, 39: 787-92.

— 'Edema and uremia from 1827 to 1905: the first faltering steps of renal pathophysiology', Kidney International, 1993, 43: 1385-96.

_ 'Osmotic diuresis before Homer W. Smith: a winding path to renal physiology', Kidney International, 1994, 45: 1241-52.

Ritz, E., Küster, S. and Zeier, M., 'Clinical nephrology in 19th century Germany', Am. J Nephrol., 1994, 14: 443-7. 


\section{Selected Bibliography}

— Zeier, M. and Lundin, P., 'French and German nephrologists in the mid-19th century: the impact of Richard Bright on the continent', Am. J. Nephrol., 1989, 9: 167-72.

Warner, J. H., 'Contested traditions: John Hughes Bennett and the bloodletting controversy', Proc. R. Coll. Physicians (Edin.), 1997, 27 (Supp. 3): 22-31.

Wellcome, Henry S., 'The evolution of urine analysis: an historical sketch of the clinical examination of urine', Lecture memoranda, American Medical Association, London and New York, Burroughs Wellcome and Co., 1911.

For further articles/papers on Pierre-François Olive Rayer see Professor Stewart Cameron's Bibliography of the History of Nephrology at http://www.isn-online.org 